\title{
Total IgE levels are linked to the response of chronic spontaneous urticaria patients to omalizumab
}

\begin{tabular}{|c|c|}
\hline Journal: & Allergy \\
\hline Manuscript ID & ALL-2018-00264 \\
\hline Wiley - Manuscript type: & Letter to the Editor \\
\hline Date Submitted by the Author: & 28-Mar-2018 \\
\hline Complete List of Authors: & $\begin{array}{l}\text { Weller, Karsten; Charite - Universitätsmedizin Berlin, Dermatology and } \\
\text { Allergy } \\
\text { Ohanyan, Tatevik; Charité - Universitätsmedizin Berlin, Department of } \\
\text { Dermatology and Allergy } \\
\text { Hawro, Tomasz; Charité - Universitätsmedizin Berlin, Dermatology and } \\
\text { Allergy } \\
\text { Ellrich, André; Charité - Universitätsmedizin Berlin, Department of } \\
\text { Dermatology and Allergy } \\
\text { Sussman, Gordon; University of Toronto, Division Allergy and Immunology } \\
\text { Koplowitz, Jake; University of Toronto, Division Allergy and Immunology } \\
\text { Giménez-Arnau, Ana; Hospital del Mar. Institut Mar d'Investigacions } \\
\text { Mediques, Dermatology; Consulta Gimenez Arnau, Dermatology } \\
\text { Peveling-Oberhag, Adriane; universitätsmedizin, dermatology } \\
\text { Staubach, Petra; universitätsmedizin, dermatology } \\
\text { Metz, Martin; Charité - Universitätsmedizin Berlin, Allergie-Centrum- } \\
\text { Charite, Dermatology and Allergy; } \\
\text { Maurer, Marcus; Charité - Universitätsmedizin Berlin, Department of } \\
\text { Dermatology and Allergy; }\end{array}$ \\
\hline Keywords: & urticaria, IgE, omalizumab, response, predictor, therapy, treatment \\
\hline
\end{tabular}




\section{Total IgE levels are linked to the response of chronic spontaneous urticaria} patients to omalizumab

\section{Short title: Response to omalizumab in CSU is linked to $\lg E$}

\section{To the Editor:}

Anti-lgE treatment with omalizumab was shown to be effective in chronic spontaneous urticaria (CSU) in randomized controlled trials (1) and real life studies (2) (3). Omalizumab, the first licensed therapy for $\mathrm{H}_{1}$-antihistamine refractory $\mathrm{CSU}$, prevents $\lg E$ binding to its high-affinity receptor ( $F c \varepsilon R I)$ (4). As a result, free serum IgE levels decline and the expression of FcERI receptors on basophils and mast cells is down-regulated (4). Moreover, omalizumab appears to dissociate pre-bound IgE from mast cells and basophils (4).

The exact mechanisms of action of omalizumab in CSU are not fully understood, and the therapeutic response remains difficult to predict. The characterization of responders vs. non-responders to omalizumab therapy could help to understand its mode of action and to establish predictors of response in clinical practice. Here, we compared complete responders (CR) to non-responders (NR) and partial responders (PR) to identify predictors for response. In total, we analyzed 85 patients from $4 \mathrm{GA}^{2} \mathrm{LEN}$ urticaria centers of reference and excellence (UCAREs) (5), $43 \mathrm{CR}$, $23 \mathrm{PR}$, and $19 \mathrm{NR}$ to omalizumab treatment (Table 1). Complete, partial and nonresponse was defined as the reduction of signs and symptoms by $\geq 90 \%$, by $\geq 30 \%$ but $<90 \%$, and by $<30 \%$ (physicians global assessment), respectively, after 2 fourweekly injections of omalizumab $300 \mathrm{mg}$. All centers provided data on NRs comparing patient characteristics, laboratory values, and treatment response. In addition, all centers were asked to provide data on at least one PR and CR per entered NR. Because different methods of total IgE assessment with different reference values were used, the total IgE-values were transferred to percentage scores of the respective upper reference value. Total IgE levels of $0 \%-10 \%,>10 \%$ $50 \%$, and $>50 \%-100 \%$ were regarded as low normal, mid normal, and high normal, whereas total $\operatorname{lgE}$ levels of $>100 \%-250 \%,>250 \%-1000 \%$, and $>1000 \%$ were regarded as slightly elevated, moderately elevated, and highly elevated. Statistical analyses were done with SPSS (IBM SPSS Statistics, Version 22).

No differences were found between the three responder groups (CR, PR, and NR) 
with regard to age (ANOVA) and gender distribution (Chi-squared test). In contrast, disease duration (Kruskal-Wallis test, $\mathrm{p}<0.05$ ) and categorized total IgE levels were significantly different (Chi-squared test, $p<0.05$ and $p<0.001$ ), as were noncategorized total IgE percentage values (Kruskal-Wallis test, $\mathrm{p}<0.001$ ), determined before the initiation of omalizumab treatment. Patients with $\mathrm{CR}, \mathrm{PR}$ and NR exhibited median total IgE levels (percentage of upper reference value) of 204.0, 65.7, and 16.7, respectively (Table 1 ). Notably, elevated $\lg E$ levels were found in the majority (77.5\%) of CR, in $31.8 \%$ of PR and only in $20.0 \%$ of NR to omalizumab (Chi-squared test, $\mathrm{p}<0.001$ ) (Figure 2). In contrast, $40.0 \%$ of the NR showed low normal IgE levels, as compared to $27.3 \%$ of the PR and only $2.5 \%$ of the CR (Chi-squared test, $\mathrm{p}<0.005)$. The age, gender, or disease duration of patients with normal and low normal IgE levels did not differ significantly between the three responder groups. In the population studied, the positive predictive value of elevated total $\lg E$ levels for CR was $75.6 \%$, and the positive predictive value of a total $\lg E \leq 10 \%, \leq 50 \%$, and $\leq 100 \%$ (normal levels) of the upper reference value for NR and PR (non-CR) was $92.3 \%, 85.2 \%$, and $75.0 \%$, respectively.

In summary, we found that elevated total lgE levels were common in CR and only rarely detectable in NR to omalizumab. In contrast and more importantly, normal and particularly low normal total lgE levels were prevalent in NR and only rarely detectable in CR. However, normal and low total lgE levels were found in all responder types, and we failed to identify a cut-off for total IgE levels for NR. Accordingly, the total lgE level of patients cannot be used as a stand alone predictor of response to omalizumab. Additional markers are needed to fully distinguish between patients who will or will not respond to omalizumab, especially those with low total lgE.

As of yet, the different omalizumab responder groups remain ill defined. Recently, Deza et al. (6) found FceRI expression levels on basophils before omalizumab treatment to be significantly lower in NR than in responders. They also demonstrated that, after initiation of omalizumab therapy, a significant drop by almost $90 \%$ in the basophil FceRI expression occurred 4 weeks after the first dose with the reduction being lower in NR as compared to responders. Accordingly, the authors regard basophil FceRI receptor expression as a potential immunological predictor of response. In accordance with our work, Deza and coworkers also found that responders present higher total $\lg E$ levels at baseline and a positive correlation 
69 between $\lg E$ levels and basophil FcERI expression. One possible explanation for 70 these and our findings are that two types of autoimmunity exist in CSU (7), i.e. type I 71 autoimmunity (driven by IgE-autoantibodies against autoantigens such as TPO) (8)

72 73 74 75 and type Ilb autoimmunity (diagnosed by a positive basophil activation test [BAT], which is held to be caused by mast cell activating IgG-autoantibodies, e.g. against the IgE receptor, FcERI). Indeed, Palacios et al. recently found a link between a positive BAT and a lower response rate to omalizumab (9), although their findings were not totally consistent. It may be possible that both predictors of response, a positive BAT and low total IgE levels describe the same patients, i.e. those with type Ilb autoimmunity. Future prospective studies should combine both predictors in order to determine if this increases the precision of the response prediction.

The strength of our study is the multicenter approach and evaluation of patients from all responder groups. The weaknesses are that the data were analyzed retrospectively, the number of patients included were low, the definition of response is based on a physician's global assessment and not backed by urticaria activity score data, and that we could only assess response after 2 injections of omalizumab but not at later time points during treatment.

In conclusion, there is a link between baseline total $\operatorname{lgE}$ levels and response to omalizumab treatment in CSU patients, with elevated total IgE levels being frequent and low levels of total IgE being infrequent in CR. Prospective studies are needed to confirm our observations. 


\section{References}

1. Zhao ZT, Ji CM, Yu WJ, Meng L, Hawro T, Wei JF, et al. Omalizumab for the treatment of chronic spontaneous urticaria: A meta-analysis of randomized clinical trials. J Allergy Clin Immunol 2016;137(6):1742-1750 e1744.

2. Gericke J, Metz M, Ohanyan T, Weller K, Altrichter S, Skov PS, et al. Serum autoreactivity predicts time to response to omalizumab therapy in chronic spontaneous urticaria. J Allergy Clin Immunol 2017;139(3):1059-1061 e1051. 3. Metz M, Ohanyan T, Church MK, Maurer M. Omalizumab is an effective and rapidly acting therapy in difficult-to-treat chronic urticaria: a retrospective clinical analysis. J Dermatol Sci 2014;73(1):57-62.

4. Metz M, Staubach P, Bauer A, Brehler R, Gericke J, Kangas M, et al. Clinical efficacy of omalizumab in chronic spontaneous urticaria is associated with a reduction of FcepsilonRI-positive cells in the skin. Theranostics 2017;7(5):1266-1276. 5. Maurer M, Metz M, Bindslev-Jensen C, Bousquet J, Canonica GW, Church MK, et al. Definition, aims, and implementation of GA(2) LEN Urticaria Centers of Reference and Excellence. Allergy 2016;71(8):1210-1218.

6. Deza G, Bertolin-Colilla M, Pujol RM, Curto-Barredo L, Soto D, Garcia M, et al. Basophil FcepsilonRI Expression in Chronic Spontaneous Urticaria: A Potential Immunological Predictor of Response to Omalizumab Therapy. Acta Derm Venereol 2017.

7. Kolkhir P, Church MK, Weller K, Metz M, Schmetzer O, Maurer M. Autoimmune chronic spontaneous urticaria: What we know and what we do not know. J Allergy Clin Immunol 2017;139(6):1772-1781 e1771.

8. Altrichter S, Peter HJ, Pisarevskaja D, Metz M, Martus P, Maurer M. IgE mediated autoallergy against thyroid peroxidase--a novel pathomechanism of chronic spontaneous urticaria? PLoS One 2011;6(4):e14794.

9. Palacios T, Stillman L, Borish L, Lawrence M. Lack of basophil CD203cupregulating activity as an immunological marker to predict response to treatment with omalizumab in patients with symptomatic chronic urticaria. J Allergy Clin Immunol Pract 2016;4(3):529-530.

Karsten Weller, MD

Tatevik Ohanyan, $M D^{a}$

Tomasz Hawro, MDa

André Ellrich, $B S c^{a}$

Gordon Sussman, $M D^{b}$

Jake Koplowitz, $B S c^{b}$

Ana Maria Gimenez-Arnau, $M D^{c}$

Adriane Peveling-Oberhag, $M D^{d}$

Petra Staubach, $M D^{d}$

Martin Metz, $M D^{a}$

Marcus Maurer, MDa 
138 From athe Department of Dermatology and Allergy, Allergie-Centrum-Charité, Charité 139 - Universitätsmedizin Berlin, Germany; b the Division of Allergy and Clinical 140 Immunology, St Michael's Hospital and University of Toronto, Toronto, ON, Canada;

141 cthe Department of Dermatology, Hospital del Mar, iMIM, Universitat Autonoma of 142 Barcelona, Barcelona, Spain; dthe Department of Dermatology, University Medical 143 Center Mainz, Mainz, Germany

144

145 Funding:

146 None

147

148

149

Conflict of interest:

150 Karsten Weller: Consultant/speaker for and recipient of research funds made 151 available to my university by Novartis.

152 Tatevik Ohanyan: None.

153 Tomasz Hawro: None.

154 André Ellrich: None.

155 Gordon Sussman: Consultant/speaker for and recipient of research funding by 156 Novartis and Genentech.

157 Jake Koplowitz: None.

158 Ana Giménez-Arnau: Consultant/speaker for and recipient of research funds made 159 available to my university by Novartis and Genentech.

160 Adriane Peveling-Oberhag: Consultant/speaker for and recipient of research funds 161 made available to my university by Novartis.

162 Petra Staubach: Consultant/speaker for and recipient of research funds made 163 available to my university by Novartis.

164 Martin Metz: Consultant/speaker for and recipient of research funds made available 165 to my university by Novartis and Genentech.

166 Marcus Maurer: Consultant/speaker for and recipient of research funds made 167 available to my university by Novartis and Genentech. 


\section{Statement of contribution:}

171 Karsten Weller: Substantial contributions to conception and design, acquisition of 172 data, and interpretation of data; drafting the article and revising it critically for 173 important intellectual content; final approval of the version to be submitted and any 174 revised version.

175 Tatevik Ohanyan: Substantial contributions to acquisition of data, interpretation of 176 data; revising the article critically for important intellectual content; final approval of 177 the version to be submitted and any revised version.

178 Tomasz Hawro: Substantial contributions to analysis and interpretation of data; 179 revising the article critically for important intellectual content; final approval of the 180 version to be submitted and any revised version.

181 André Ellrich: Substantial contributions to analysis and interpretation of data; revising 182 the article critically for important intellectual content; final approval of the version to 183 be submitted and any revised version.

184 Gordon Sussman: Substantial contributions to conception and design, and 185 acquisition of data; revising the article critically for important intellectual content; final 186 approval of the version to be submitted and any revised version.

187 Jake Koplowitz: Substantial contributions to acquisition of data; revising the article 188 critically for important intellectual content; final approval of the version to be 189 submitted and any revised version.

190 Ana Giménez-Arnau: Substantial contributions to conception and design, and 191 acquisition of data; revising the article critically for important intellectual content; final 192 approval of the version to be submitted and any revised version.

193 Adriane Peveling-Oberhag: Substantial contributions to acquisition of data; revising 194 the article critically for important intellectual content; final approval of the version to 195 be submitted and any revised version.

196 Petra Staubach: Substantial contributions to acquisition of data; revising the article 197 critically for important intellectual content; final approval of the version to be 198 submitted and any revised version. 
199 Martin Metz: Substantial contributions to conception and design, and interpretation of 200 data; drafting the article and revising it critically for important intellectual content; final 201 approval of the version to be submitted and any revised version.

202 Marcus Maurer: Substantial contributions to conception and design, and 203 interpretation of data; drafting the article and revising it critically for important 204 intellectual content; final approval of the version to be submitted and any revised 205 version.

206

207

208 Corresponding Author:

209 Karsten Weller, M.D.

210 Allergie-Centrum-Charité

211 Department of Dermatology and Allergy

212 Charité - Universitätsmedizin Berlin

213 Charitéplatz 1

214 D-10117 Berlin

215 Germany

216 Tel: +49-30-450-518438

217 Fax: +49-30-450-518972

218 E-mail: karsten.weller@charite.de 
Table 1 - Baseline characteristics

\begin{tabular}{|c|c|c|c|c|c|}
\hline & $\begin{array}{c}\text { All } \\
\text { patients }\end{array}$ & $\begin{array}{l}\text { Complete } \\
\text { responder } \\
\text { (CR) }\end{array}$ & $\begin{array}{l}\text { Partial } \\
\text { responder } \\
\text { (PR) }\end{array}$ & $\begin{array}{l}\text { Non- } \\
\text { responder } \\
(\mathrm{NR})\end{array}$ & \\
\hline $\mathbf{N}$ of patients & $\mathrm{n}=85$ & $n=43$ & $\mathrm{n}=23$ & $\mathrm{n}=19$ & \\
\hline $\begin{array}{l}\text { Age in years } \\
\text { (mean } \pm S D \text {, } \\
\text { median) }\end{array}$ & $\begin{array}{c}44.3 \pm 15.2 \\
43\end{array}$ & $\begin{array}{c}45.6 \pm 15.6 \\
47\end{array}$ & $\begin{array}{c}42.7 \pm 14.0 \\
39\end{array}$ & $\begin{array}{c}43.3 \pm 16.3 \\
43\end{array}$ & n.s. ${ }^{*}$ \\
\hline $\begin{array}{l}\text { Gender } \\
\text { (female : male) }\end{array}$ & $\begin{array}{c}67: 18 \\
(79 \%: 21 \%)\end{array}$ & $\begin{array}{c}35: 8 \\
(81 \%: 19 \%)\end{array}$ & $\begin{array}{c}17: 6 \\
(74 \%: 26 \%)\end{array}$ & $\begin{array}{c}15: 4 \\
(79 \%: 21 \%)\end{array}$ & n.s. ${ }^{* *}$ \\
\hline $\begin{array}{l}\text { Disease duration } \\
\text { in months } \\
\text { (mean } \pm S D \\
\text { median) }\end{array}$ & $\begin{array}{c}81.6 \pm 91.0 \\
50\end{array}$ & $\begin{array}{c}81.0 \pm 82.7 \\
53\end{array}$ & $\begin{array}{c}101.0 \pm 95.4 \\
93\end{array}$ & $\begin{array}{c}59.6 \pm 103.0 \\
18\end{array}$ & $p<0.05^{\star * *}$ \\
\hline $\begin{array}{l}\text { Total IgE levels } \\
\text { in percent of upper } \\
\text { reference value } \\
\text { (mean } \pm \text { SD; } \\
\text { median, IQR) }\end{array}$ & $\begin{array}{c}430.6 \pm \\
1299.0 \\
119.0 \\
30.1-355.0\end{array}$ & $\begin{array}{c}491.4 \pm \\
994.9 \\
204.0 \\
113.8-437.5\end{array}$ & $\begin{array}{c}573.0 \pm \\
2033.6 \\
56.7 \\
9.9-242.0\end{array}$ & $\begin{array}{c}59.4 \pm \\
93.4 \\
16.7 \\
8.4-32.4\end{array}$ & $\begin{array}{l}p<0.001^{\star * *}, \\
p<0.001^{\dagger} \\
p<0.05^{\dagger \dagger} \\
p=0.36^{\dagger \dagger}\end{array}$ \\
\hline
\end{tabular}

${ }^{*}$ comparison of CR, PR, and NR using ANOVA

${ }^{* *}$ comparison of CR, PR, and NR using Chi-squared-test

${ }^{* * *}$ comparison of CR, PR, and NR using Kruskal-Wallis-test

'comparison of NR vs. CR using Dunn's post hoc test (corrected for multiple comparisons)

${ }^{\dagger \dagger}$ comparison of PR vs. CR using Dunn's post hoc test (corrected for multiple comparisons)

${ }^{\mathrm{tt+}}$ comparison of NR vs. PR using Dunn's post hoc test (corrected for multiple comparisons) 
240

241

242

243

244

245

246

247

248

\section{Figure 1 - Response to omalizumab is linked to total IgE levels}

Total $\lg E$ levels before the initiation of omalizumab were categorized based on their upper reference value into low normal ( $0 \%-10 \%)$, mid normal (>10\%-50\%), high normal (>50\%$100 \%)$, slightly elevated (>100\%-250\%), moderately elevated (>250\%-1000\%) and strongly elevated $(>1000 \%)$. The proportions of patients with these total IgE level categories are shown for complete responders, partial responders and non-responders defined by a reduction of signs and symptoms $\geq 90 \%$, $\geq 30 \%$ but $<90 \%$, and $<30 \%$ (physicians global assessment), respectively.

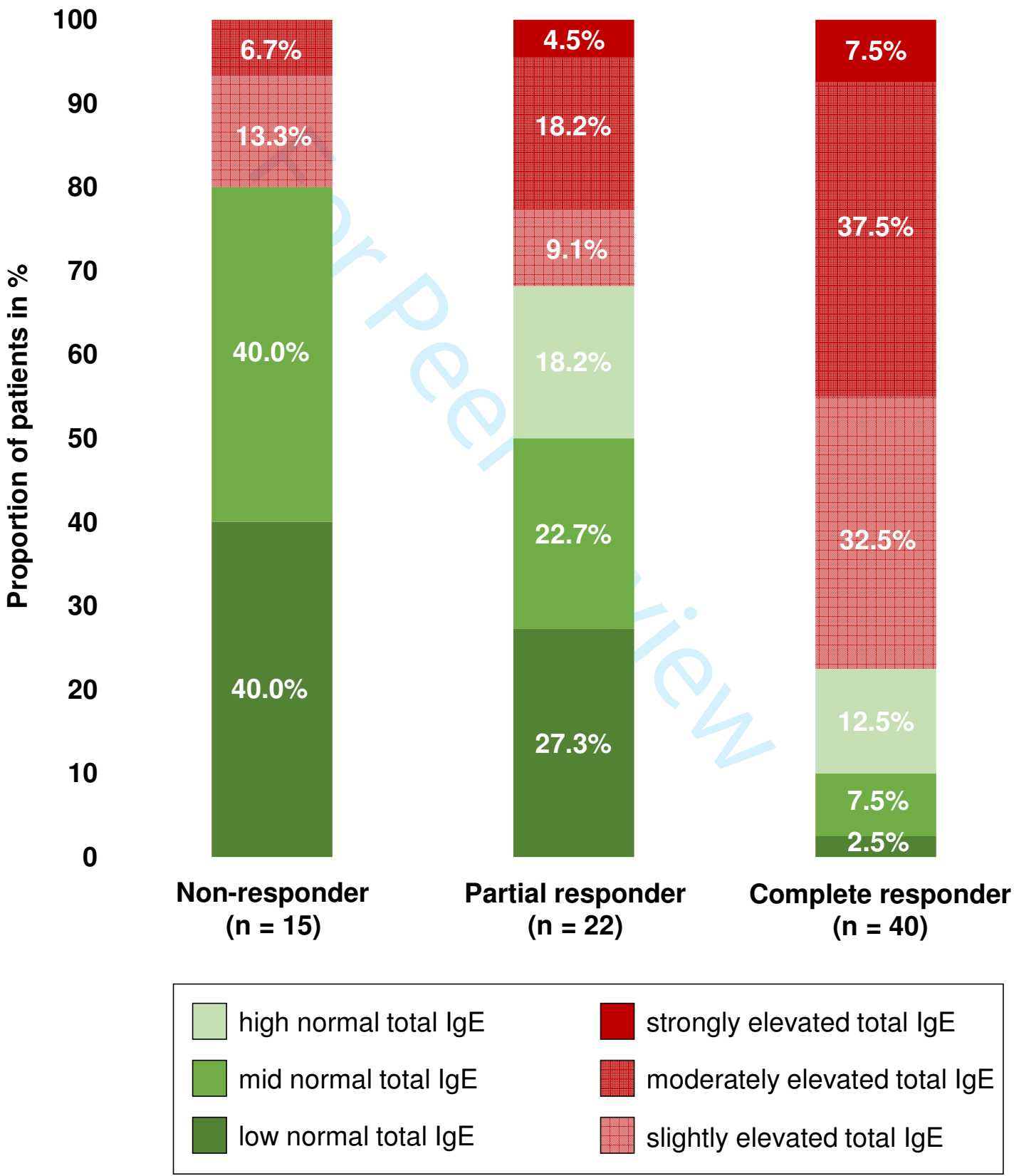

